\title{
Changes in Global Tropospheric OH Expected as a Result of Climate Change Over the Last Several Decades
}

Julie M. Nicely ${ }^{1}$, R. J. Salawitch ${ }^{1}$, T. Canty ${ }^{1}$, A. R. Douglass², B. N. Duncan², C. Lang ${ }^{3}$, Q. Liang ${ }^{2}$, L. D. Oman'2, J. M. Rodriguez², R. S. Stolarski ${ }^{3}$, S. Strode ${ }^{2,4}$, D. W. Waugh ${ }^{3}$ ${ }^{1}$ University of Maryland, College Park, Md; ${ }^{2}$ NASA Goddard Space Flight Center, Greenbelt, Md; ${ }^{3}$ Johns Hopkins University, Baltimore, Md; ${ }^{4}$ Universities Space Research Association, Columbia, Md
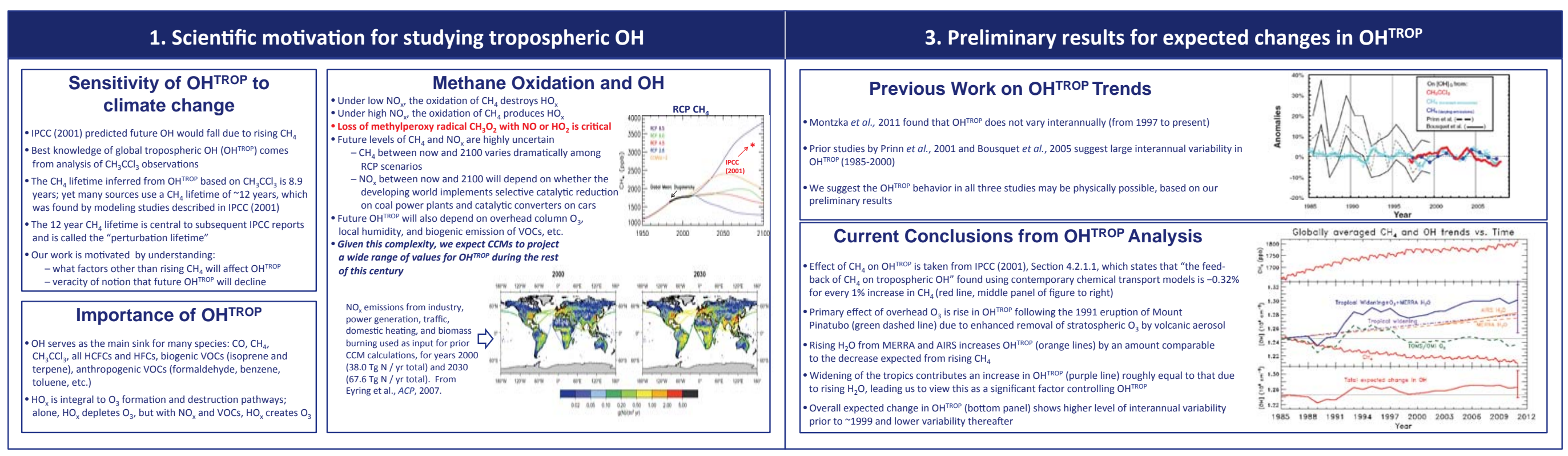

\section{Methods for estimating changes in $\mathrm{OH}^{\mathrm{TROP}}$}

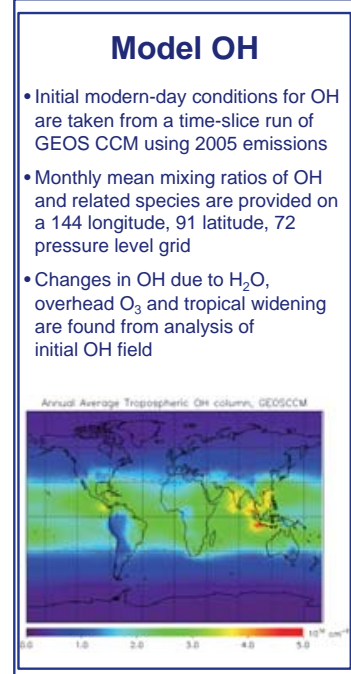

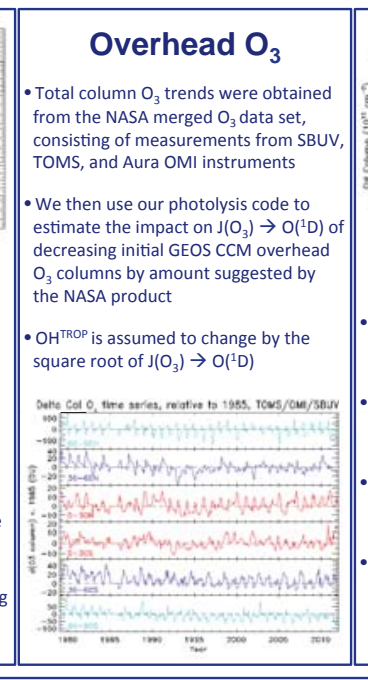

4. Future plans for refining estimates of $\Delta \mathrm{OH}^{\mathrm{TROP}}$

\begin{tabular}{|c|}
\hline $\begin{array}{l}\text { Improve Estimate of } \\
\mathrm{d}\left(\mathrm{OH}^{\mathrm{TROP}}\right) / \mathrm{d}\left(\mathrm{H}_{2} \mathrm{O}\right)\end{array}$ \\
\hline $\begin{array}{l}\text { - Reaction rates from recent runs of GEOS CCM } \\
\text { are archived for reactions such as: }\end{array}$ \\
\hline $\mathrm{H}_{2} \mathrm{O}+\mathrm{O}\left({ }^{1} \mathrm{D}\right) \rightarrow 2 \mathrm{OH}$ \\
\hline $\begin{array}{l}\text { - Using these reaction rates we will determine } \\
\text { the proportion of } \mathrm{OH} \text { that is produced via } \\
\text { reaction with } \mathrm{H}_{2} \mathrm{O}\end{array}$ \\
\hline $\begin{array}{l}\text { - The determined scaling factor would be used to } \\
\text { calculate a new } \triangle \mathrm{OH}^{\mathrm{TROP}} \text { based on the } \mathrm{H}_{2} \mathrm{O} \\
\text { trends }\end{array}$ \\
\hline $\begin{array}{l}\text { - Estimate time- and pressure-varying values of } \\
\mathrm{d}\left(\mathrm{OH}^{\mathrm{TROP}}\right) / \mathrm{d}\left(\mathrm{H}_{2} \mathrm{O}\right)\end{array}$ \\
\hline $\begin{array}{l}\text { - Evaluate discrepancies between MERRA and } \\
{ }_{\mathrm{AlRS}} \mathrm{H}_{2} \mathrm{O} \text { trends }\end{array}$ \\
\hline
\end{tabular}

Propagate Uncertainties

- Calculate uncertainties in AIRS and MERRA
$\mathrm{H}_{2} \mathrm{O}$ and NASA $\mathrm{O}_{3}$ product

\begin{tabular}{|c|}
\hline Evaluate $\mathrm{CH}_{4} / \mathrm{OH}$ Feedback \\
\hline $\begin{array}{l}\text { We will use a box model (details below) to proro } \\
\text { relationship between } \mathrm{CH}_{4} \text { and } \mathrm{OH}^{\text {Troop and }} \text { its } \\
\text { dependence on } \mathrm{N}_{x}\end{array}$ \\
\hline 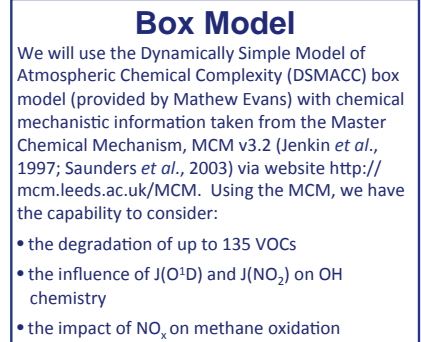 \\
\hline
\end{tabular}

- Evaluate standard deviation in average fraction of $\mathrm{OH}$ production occurring via $\mathrm{H}_{2} \mathrm{O}+\mathrm{O}(' \mathrm{D})$ - Estimate uncertainty in the box mode
evaluation of $\mathrm{d}\left(\mathrm{OH}^{\mathrm{T} P O P}\right) / \mathrm{d}\left(\mathrm{CH}_{4}\right)$
Assessing $\mathrm{OH}^{\mathrm{TROP}}$ in $\mathrm{CCMs}$ - Through our involvement with the IGAC / SPARC Chemistry-
requested: 1. hourly, instantaneous output from participatit
CCMs 1 day/season, 1 year/decade 2. archival of all species, reaction rates, $J$-values, and physical parameters relevant to $\mathrm{OH}$ chemistry 3. this output for both the REF-C1 (hindcast) and REF-C2 (future) runs

We plan to assess the causes of differences between $\mathrm{OH}$ in the CCMS - Use of the box model enables us to distinguish mechanism and those due to differences in $\mathrm{OH}$ precursors We can also use this output to predict future trends the future CCM runs 